\title{
Integration of numerical models and geoinformatic techniques in the delimitation of a protection zone for the MGB 319 complex multi-aquifer system in southwest Poland
}

\author{
Jacek Gurwin \\ Department of Hydrogeology, Wrocław University, Max Born Square 9, 50-205 Wrocław, Poland; \\ e-mail: jacek.gurwin@uwr.edu.pl
}

\begin{abstract}
The study area, situated near the city of Wrocław in southwest Poland, is part of the hydrogeological system of the Quaternary/Neogene MGB 319, inclusive of a buried valley of high water potential, named the Bogdaszowice structure. This structure is an alternative source of water supply for the Wrocław city area. Numerical modelling is the most effective tool in establishing a groundwater protection strategy for Major Groundwater Basins (MGBs) in complex aquifer systems. In the present study, the first step was to assess the hydrodynamic conditions of the Radakowice groundwater intake by analyses of head contours, pathlines, average flow times and capture zones of particular wells. Subsequently, these results were used in combination with other data and compiled as GIS layers. The spatial distribution of hydraulic conductivity was based on the lithology of surface sediments. Other data sets such as the thickness of the unsaturated zone, average soil moisture and infiltration rate were taken either directly from the model or were calculated. Based on the input data obtained, vertical flow time calculations for every model cell were made. The final outcome is a map of the protection zone for the aquifer system of the MGB 319.
\end{abstract}

Keywords: numerical groundwater modelling, GIS, unsaturated zone, MGB, central Europe

\section{Introduction}

The aim of the present paper is to provide an overview of current research and methodology for the development of numerical models of Major Groundwater Basins (MGBs) that are characterised by complex multi-layered conditions. The total of 163 MGBs were documented as regions with good groundwater quality and the most beneficial exploitation conditions in Poland (Kleczkowski, 1990; Herbich et al., 2009). This is the reason why a special protection strategy should be applied so as to avoid degradation of groundwater quality and quantity.

A conceptualisation of the groundwater flow system within the Quaternary/Neogene complex MGB 319 near the city of Wrocław in southwest Po- land was a crucial step in the development of a 3-D numerical model. The most important element within this MGB is the Bogdaszowice structure a buried valley filled with sand and gravel deposits of high transmissivity. A large groundwater intake, consisting of several wells, is located in this area. This will be used for the water supply of Wroclaw in future.

A 3-D representation of hydrostratigraphic unit interfaces was worked out using data obtained from boreholes and utilising GIS and geostatistical analysis. A GMS MODFLOW model (McDonald \& Harbaugh, 1988; Harbaugh et al., 2000), integrated with geoinformatic techniques and advanced GIS tools (Gurwin \& Lubczyński, 2005; Gurwin \& Serafin, 2007, 2008; Gurwin, 2010), was employed to 
assess the flow system, groundwater resources and protection zone of the Bogdaszowice structure. The extent of the entire model domain was much wider in order to identify recharge zones and the influence on the area of intake. Most of the boundary conditions of such a regional model are consistent with natural hydraulic boundaries. After calibration of the groundwater flow model, particle tracking simulations were performed in a MODPATH environment in order to compute flow velocities, isochrones and travel times. In addition to flow time in aquifer, characteristics of overlying strata also have a large impact on protection of the structure on account of infiltration time through the unsaturated zone. Appropriate lithological maps of near-surface sediments, the thickness of the unsaturated zone and average soil moisture were compiled. The infiltration rate was calculated from the saturated flow model. These data, with the use of raster calculator in GIS, allowed a map of vertical flow time distribution of potential conservative pollutant to be drawn up. Combining results obtained, the protection zone of the Bogdaszowice structure was established; the most vulnerable area is located to the southwest of the structure boundary.

\section{Study area}

A buried valley structure near Bogdaszowice, located on the border between the Wroclawska Plain and Sredzka Upland, several kilometers west of Wroclaw (Fig. 1), belongs to the MGB 319. The study area is situated within the Odra River basin; it is drained by the Bystrzyca and Strzegomka rivers (as tributaries of the Odra River) and by some other, smaller streams. The altitude of the area decreases from west to east, from 150-165 m a.s.l. to approximately $120 \mathrm{~m}$ a.s.l. With reference to the regional hydrogeological division of Poland (Paczyński \& Sadurski, 2007), the area belongs to the southcentral Odra sub-region and the Lower Silesia region.

\section{Material and methods}

The geology of the study area is complex due to the variable extent and thickness of Quaternary and Neogene-Paleogene deposits that form the extensive cover of the plain (Fig. 2). The major aquifer consists of Quaternary glaciofluvial and fluvial sediments, mainly sand and gravel within a buried valley, as well as intramoraine sequences. A maximum thickness of $>100 \mathrm{~m}$ has been measured in the central part of the buried valley, where a large wa-

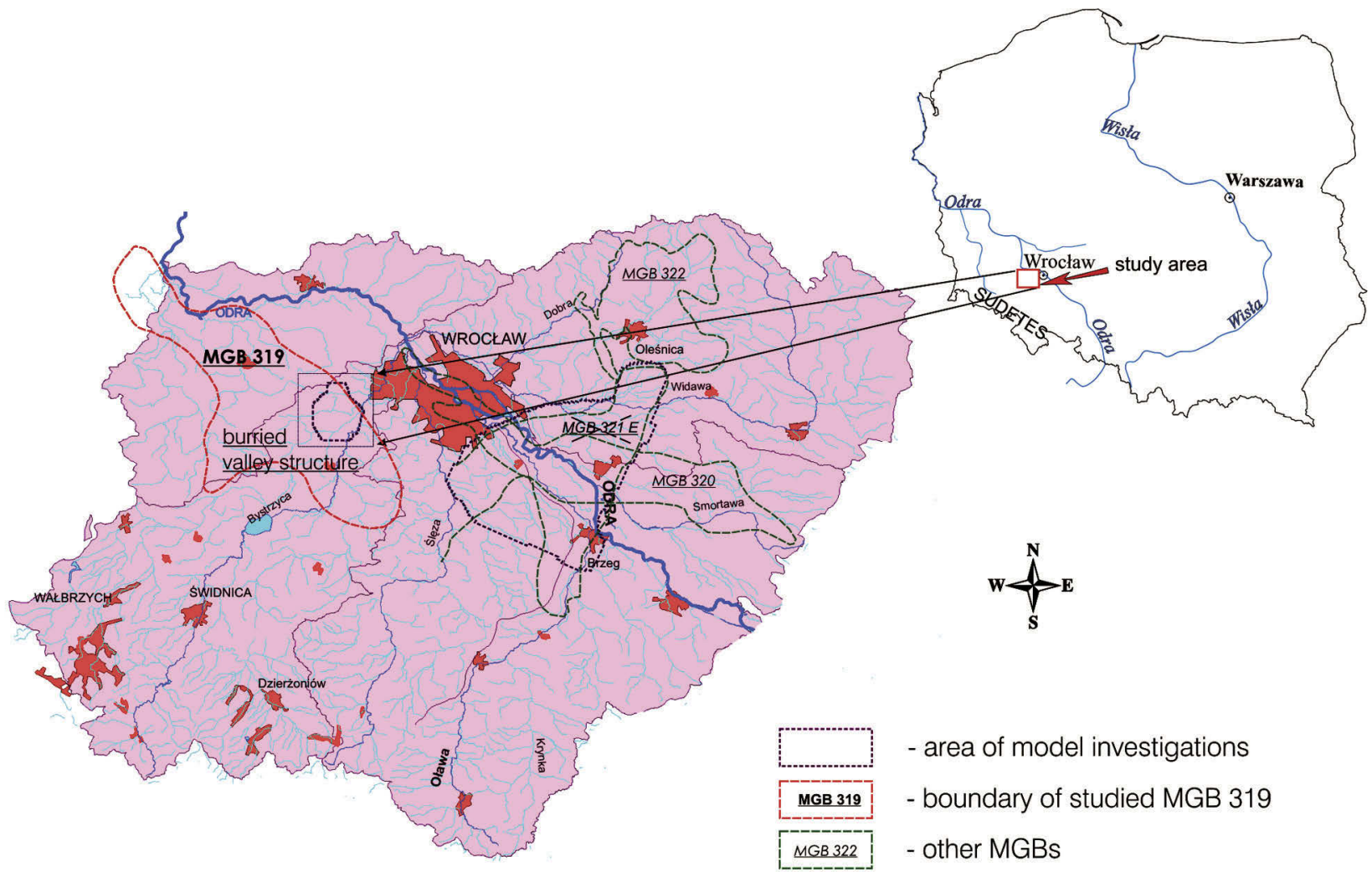

Fig. 1. Location of the MGB 319 and the buried valley structure. 


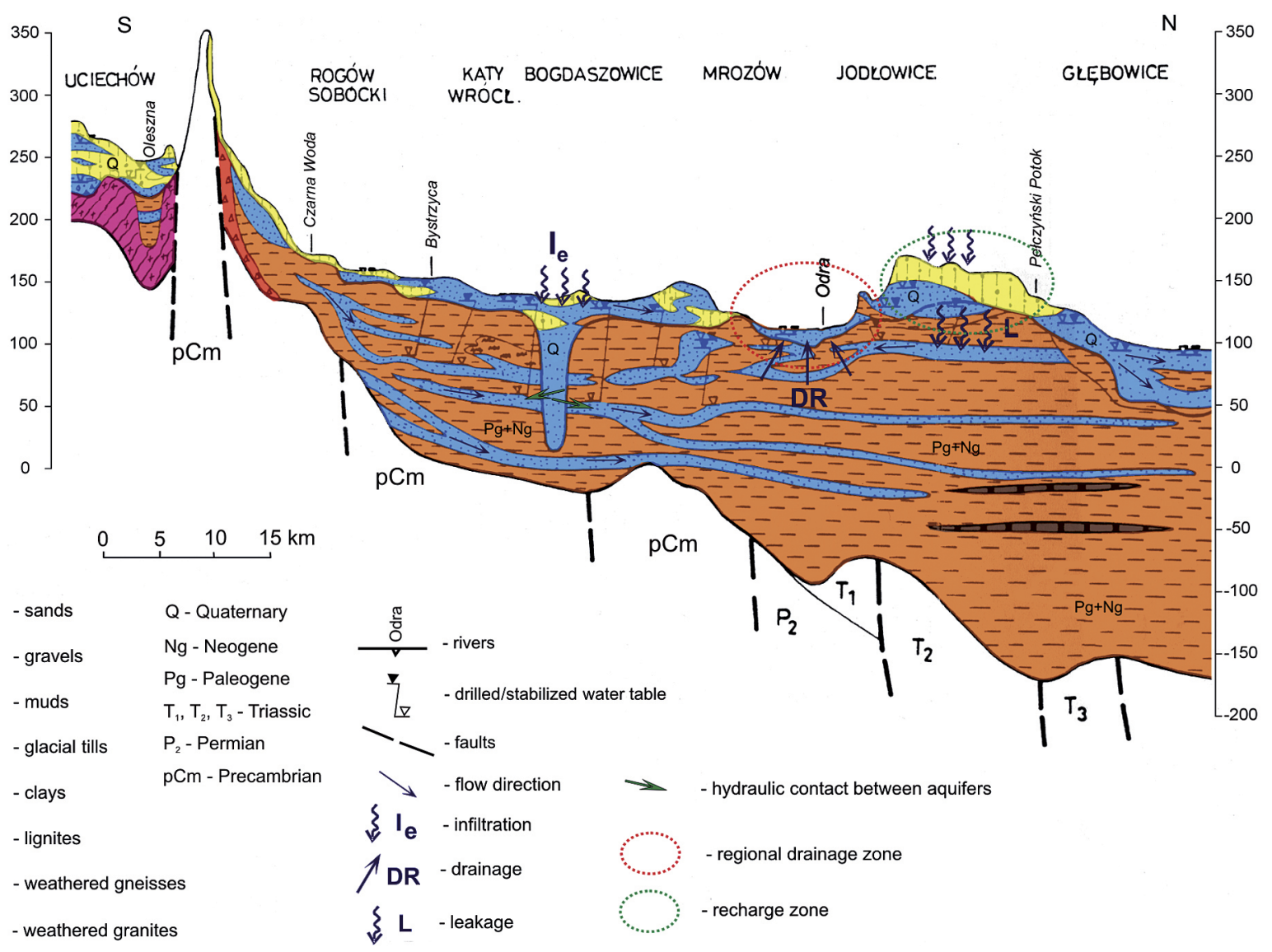

Fig. 2. Cross-section through the groundwater flow system within Quaternary/Neogene-Paleogene complexes including the MGB 319 (modified after Sachanbiński et al., 2001).

ter intake of several wells was constructed. However, this intake is not yet operational. With MGB 319 and the Bogdaszowice structure as the most promising source of good quality water to supply the Wroclaw city area, development of a numerical model for establishing protection conditions has been crucial.

\subsection{GIS modelling of water seepage time through the unsaturated zone}

To measure the protective role of near-surface sediments against pollution the time of vertical migration of conservative pollution is considered (Witczak \& Żurek, 1997).

Adopting far-reaching simplifications of the infiltration process, the estimated time of water infiltration through the unsaturated zone can be calculated according to the following, well-known formulas (Witczak \& Żurek, 1997; Witczak, 2005; Macioszczyk, 1999):

$$
\mathrm{t}_{\mathrm{a}}=\mathrm{m}_{\mathrm{a}} / \mathrm{V}_{\mathrm{a}} \quad \mathrm{V}_{\mathrm{a}}=\frac{1}{\mathrm{n}_{\mathrm{e}}} \sqrt[3]{\omega^{2} \cdot \mathrm{k}^{\prime}}
$$

or:

$$
\mathrm{t}_{\mathrm{a}}=\sum_{1}^{\mathrm{n}} \frac{\mathrm{m}_{\mathrm{i}} \cdot\left(\mathrm{w}_{\mathrm{o}}\right)}{\mathrm{I}}
$$

where: $t a$ - time of water seepage through the unsaturated zone $[\mathrm{d}], m_{i^{\prime}} m_{a}$ - thickness of the unsaturated zone [m], $w_{o}$ - soil moisture [-], $\omega$ - infiltration rate $[\mathrm{m} / \mathrm{d}], k^{\prime}$ - coefficient of vertical permeability of the unsaturated zone $[\mathrm{m} / \mathrm{d}], V_{a}$ - vertical flow velocity, $n_{e}$ - effective porosity $[-], I-$ net recharge $[\mathrm{m} / \mathrm{a}]$.

A basic input parameter to the model was a topologically correct digital elevation model (DEM) that was paramount to the establishment of overall geometry of the structure. It also helped in unambiguous mapping of the contact between surface water and groundwater. The density of contours at $2.5 \mathrm{~m}$ was taken during digitalisation of topographical maps, bearing in mind that the area near the structure is plain. A final DEM was converted to $25 \times 25-\mathrm{m}$ raster layer and due to variable density of the numerical model grid a kriging interpolation 


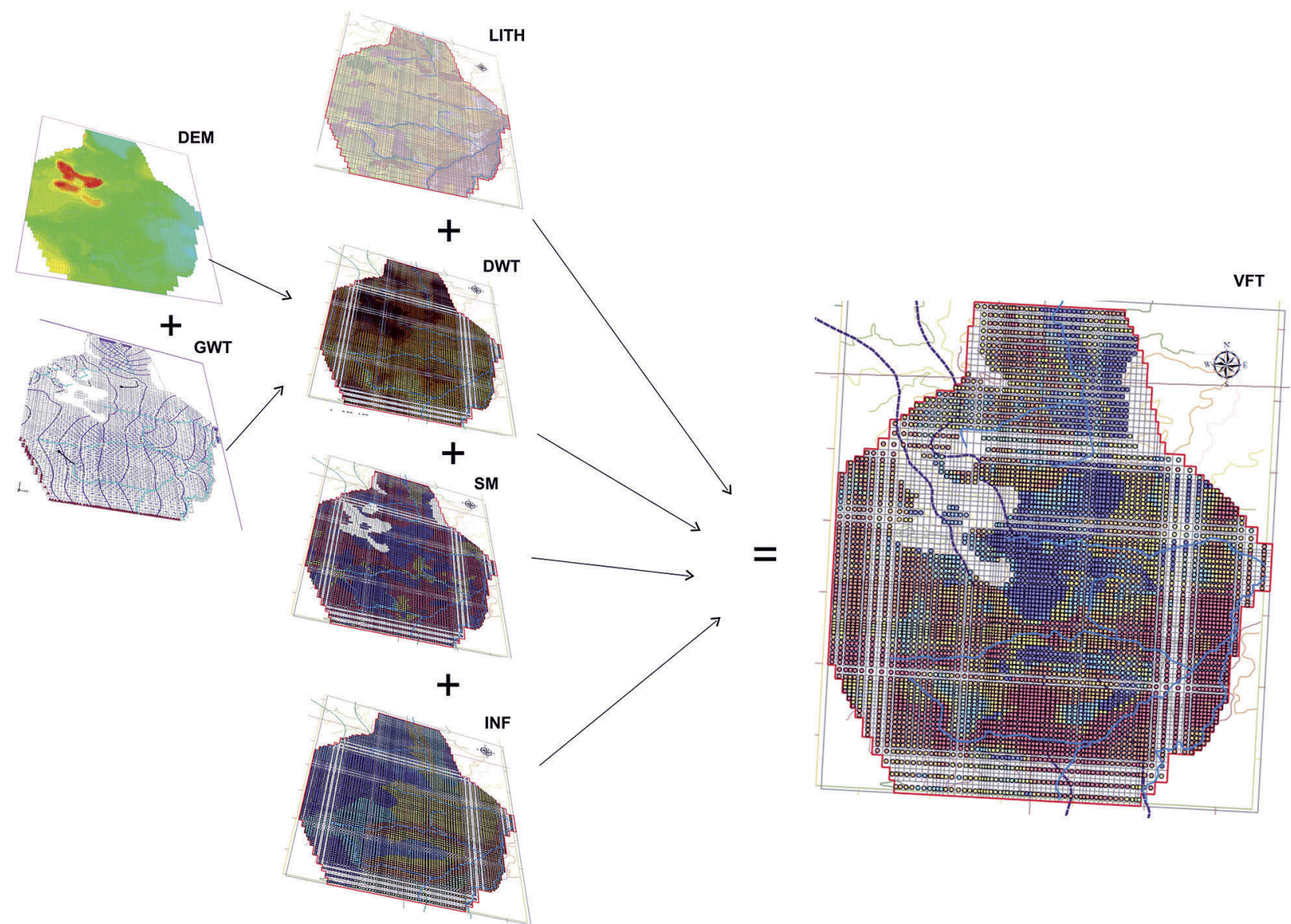

Fig. 3. Determination of average flow time through the unsaturated zone based on GIS modelling technique.

was used in order to adopt surface elevation for the blocks.

The depth to the water table surface ( $\mathrm{m} \mathrm{bgl}$ ) was calculated using DEM and groundwater elevation. The map of depth to water table (DWT) was compiled by subtracting matrices with calibrated values of heads (GWT) and surface elevation which both were taken from the numerical model. In the next step the lithological maps of near-surface sediments (LITH), the thickness of the unsaturated zone (UZT), average soil moisture (SM) and infiltration rate (INF) as a result of saturated flow model were combined using a weighted overlay technique of raster calculator in ArcGIS Spatial Analyst (Fig. 3). Finally, a spatial distribution map of vertical flow time (VFT) of potential pollutant was created (Gurwin, 2012).

\subsection{Numerical groundwater flow model}

The method of numerical modelling was applied in the area of the Bogdaszowice water-bearing structure for proper representation of groundwater flow and identification of recharge and discharge zones. On this basis several predictive simulations were performed. Hydrodynamic changes in the multilayer flow system and the impact of groundwater exploitation on the water balance components were recognised.

The grid-block dimensions ranged from a minimum of $100 \mathrm{~m}$ to a maximum of $500 \mathrm{~m}$, but most of them were between 100-200 m. Three numerical layers were introduced simulating aquifers: a late Quaternary unconfined aquifer, a major aquifer in the buried valley structure and surrounding Neogene sediments and an early Neogene aquifer. The Neogene clay series were taken as aquitards.

Boundary conditions of the I type $-\mathrm{H}=$ const. (Dirichlet) were adopted only on the groundwater outflow along the northern and partially eastern border in accordance with head contours. The III type $\mathrm{Q}=\mathrm{f}(\mathrm{H})$ of external boundary conditions (General Head Boundary Package - GHB) was treated primarily as the most appropriate for simulating a distant boundary associated with groundwater inflow along the southwestern and southern borders. The second type of boundary condition $(\mathrm{Q}=0)$ was introduced on the other margins of the grid. All active groundwater intakes in the study area were 


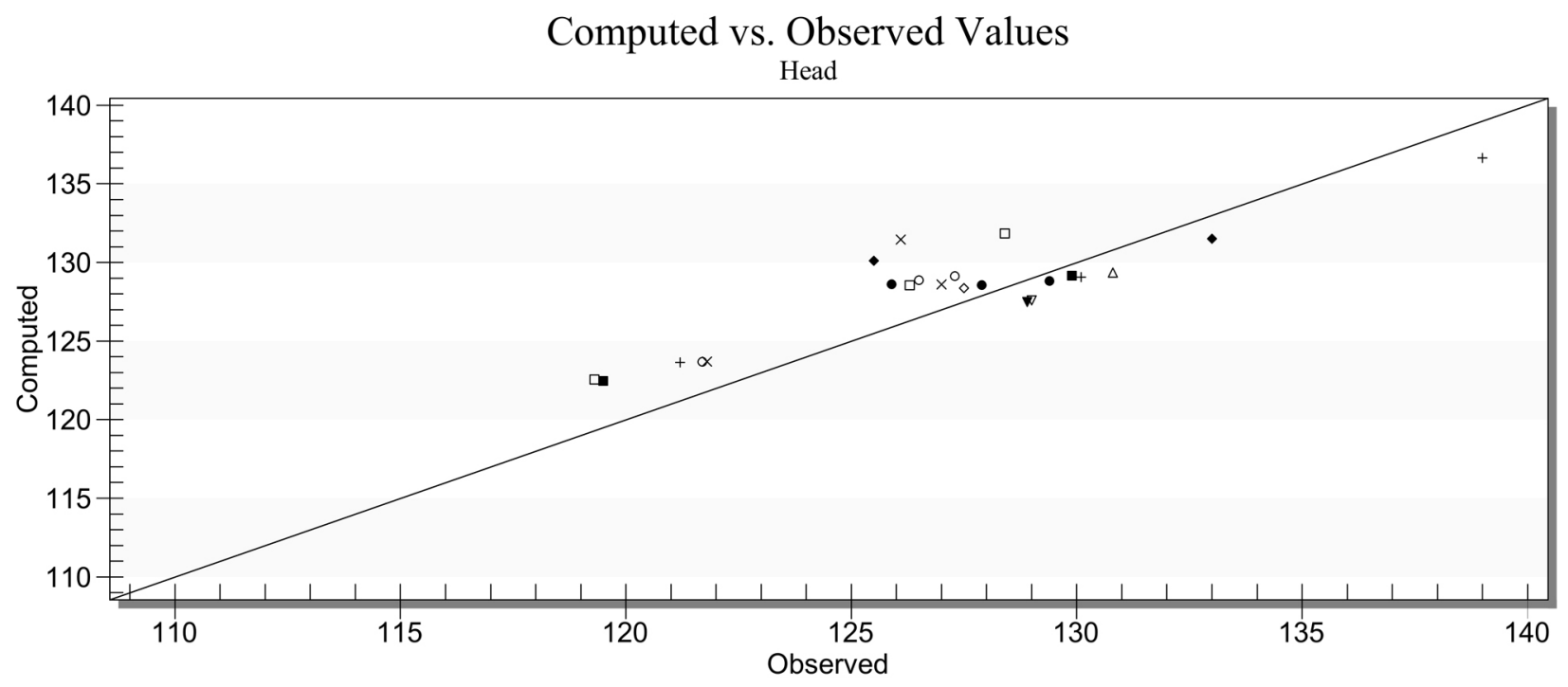

Fig. 4. Simulated versus measured heads.

modelled by internal boundary conditions of the II type $\mathrm{Q}=$ const., being equal to a pumping rate in $\mathrm{m}^{3} / \mathrm{d}$. Boundary conditions of the III type were used to simulate the interaction between groundwater and surface water in the rivers (the RIVER package). However, some small tributaries were considered as drains using the DRAIN package. Zones of recharge from infiltration were established based on surface lithology and average annual precipitation and modelled with the II type of boundary conditions $Q=$ const.

Model calibration was carried out by successive approximations, the so-called trial-and-error method. The differences between measured and calibrated head values (Fig. 4) in reference points usually are within the range of one metre in Quaternary aquifer and, in the case of the Neogene aquifer, within 1-2 metres.

Error values are as follows:

the mean error $(\mathrm{ME})$

$$
1 / n \sum_{i=1}^{n}\left(H_{p i}-H_{o i}\right)=1.02 \mathrm{~m}
$$

the mean absolute error (MAE)

$$
1 / n \sum_{i=1}^{n}\left|H_{p i}-H_{o i}\right|=1.95 \mathrm{~m}
$$

where: $H_{p}$ - measured values [L], $H_{o}$ - calculated values [L]

\section{Results and discussion}

In terms of predictive simulation and optimization of the groundwater exploitation several possible scenarios of pumping were solved, rendering a possible quantity of water for consumption of 15,000 $\mathrm{m}^{3} / \mathrm{d}$. Changes observed in the hydrodynamic system were a significant drying of the first, shallow aquifer in the recharge zones and formation of the cone of depression in the second, deeper aquifer. Due to the very high transmissivity of the deposits in the structure $\left(2,000-3,000 \mathrm{~m}^{2} / \mathrm{d}\right.$ at thicknesses of $60-90 \mathrm{~m}$ ) the cone of depression has a flattened oval shape, elongated along a northwest-southeast axis. Piezometric level drops amounted to 8-10 m.

Disposable resources of usable aquifer within the Bogdaszowice structure, based on numerical simulations, were established at $28,773 \mathrm{~m}^{3} / \mathrm{d}$, with a module of $3.36 \mathrm{l} / \mathrm{s} \mathrm{km}^{2}$ (Gurwin \& Poprawski, 2008).

Additional calculations were performed on a calibrated MODFLOW model to determine recharge areas, the actual flow rate, pathlines, flow times, capture zones, as well as to indicate properly the protection zone (Fig. 5). Forward and backward simulations were conducted to find out the distribution of pathlines in the western part which dominates in total inflow to the Bogdaszowice structure. Analyses of the individual tracks of particles in the flow system the ranges of time were run for different zones of groundwater flow. In the area located to the northwest of the structure average values were in the range of 50-100 days, in the central part between 80 and 120 days or even 200 days in the case of flow into the southern wells. The backward 
simulations allowed to identify capture zones of exploiting wells; these are presented in Figure 5. Based on MODPATH calculations, after establishing uniform time steps, isochrones were recognised and the 25-year inflow of groundwater into the wells was identified as a basis for the proposed protection zone recognition.
An analysis of the hydrogeological conditions in the area of the buried valley at Bogdaszowice, as the most important water resource structure of the entire MGB 319, indicated that the northern part was well insulated from the surface by a surging complex of tills. Calculated times of percolation through the vadose zone most significantly exceed-
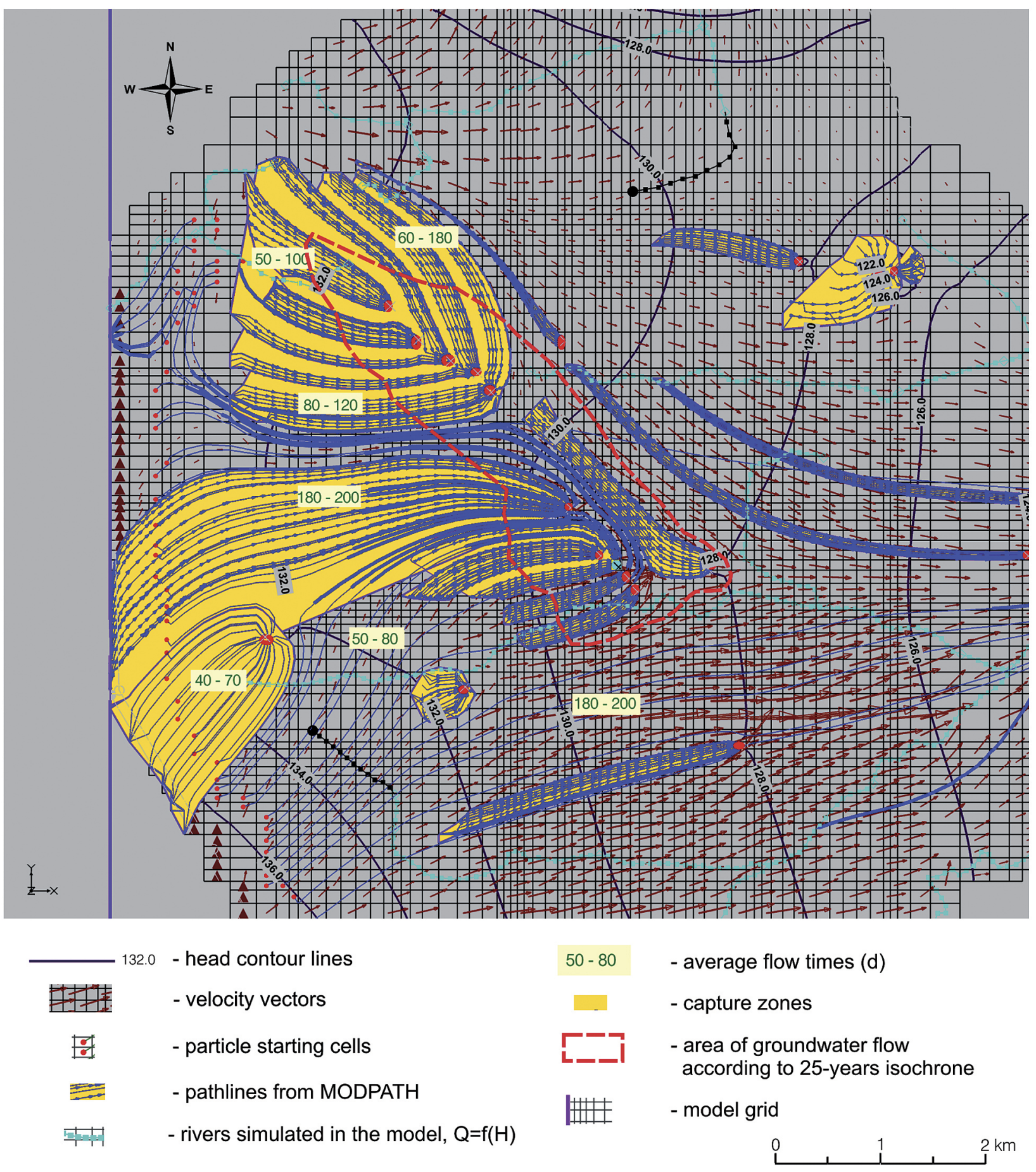

Fig. 5. Determination of capture zones and 25-year isochrone of the Radakowice intake within the Bogdaszowice structure based on the numerical flow model. 


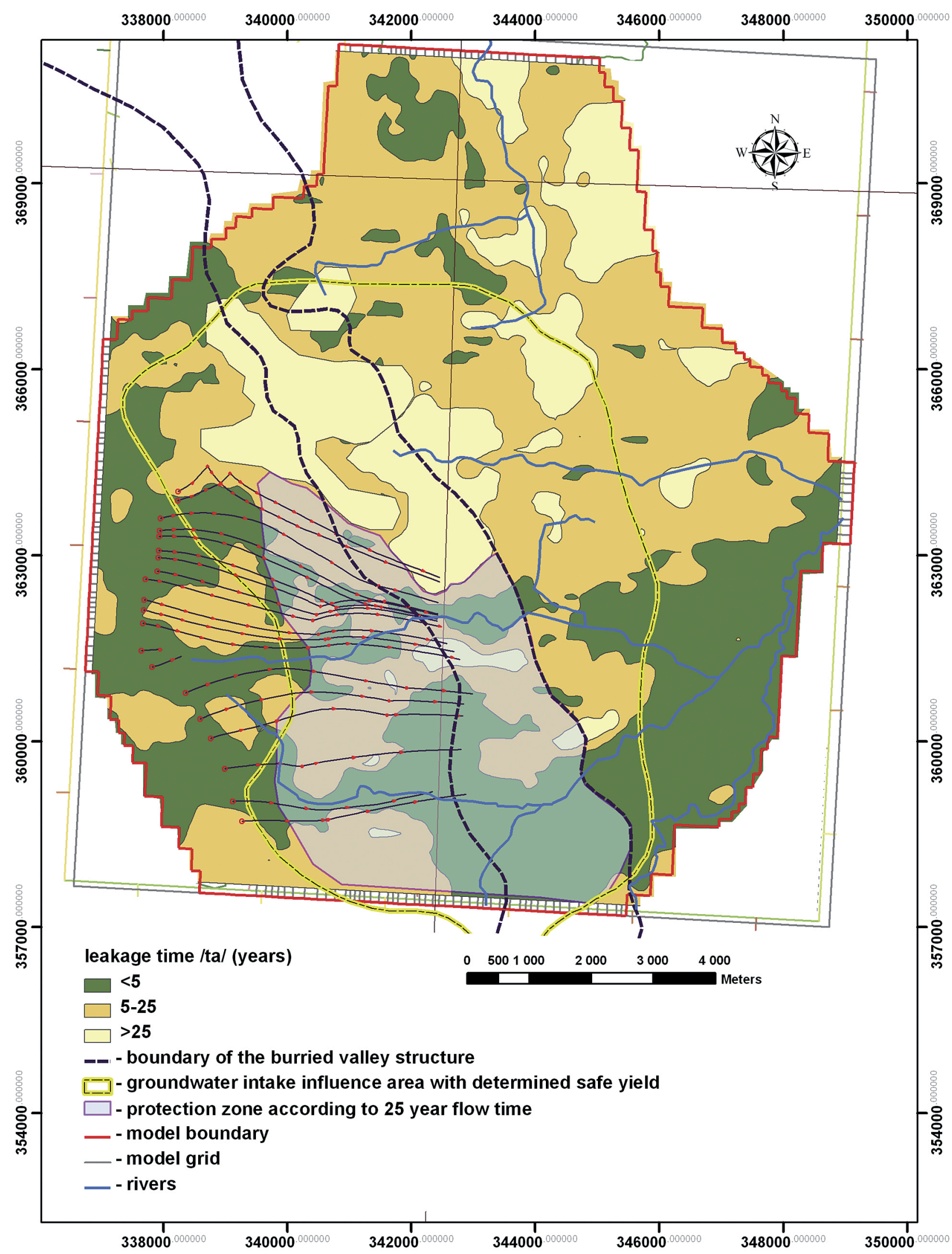

Fig. 6. Protection zone of the Bogdaszowice structure developed by combining a numerical flow model and GIS modelling. 
ed 25 years, the usable aquifer therefore not being under the influence of pollution in the current exploitation scenario. Another situation occurs in the southern part, in the area near the village of Bogdaszowice where permeable subsurface material was found and vertical flow times did not exceed 5 years. For this reason, the analysis assumed further results of lateral inflow velocities within the shallow aquifer. This inflow is formed in the recharge area that is located to the west of the boundary of the buried valley structure. The results of the numerical MODFLOW/MODPATH model in terms of hydraulic heads and flowpaths showed that the 25-year isochrone runs about 4-5 kilometres to the west (Fig. 6). Given these simulations, a boundary of the protection zone was proposed, resulting from the rate of lateral inflow combined with 5-year vertical percolation through the unsaturated zone within the structure. On the eastern side of the buried valley the directions of groundwater outflow are in accordance with the system of surface water courses, which is why the extent of the eastern boundary of the protection zone was determined to be in line with the boundary of the structure.

\section{Conclusions}

For the purposes of MGB regional model construction and derivation of protection zones, in addition to analysis of lateral inflow to aquifer boundaries, it is proposed to continue the usage of this simplified scheme for the vadose zone. A combination of the MODFLOW model results and GIS modeling is a very effective tool in this respect. The most important outcomes from the model to be utilized in protection zone delimitation are calibrated recharge values and velocity distribution with pathlines resolved by MODPATH.

A large groundwater intake, comprising several wells located in the buried valley structure within the MGB 319, was demonstrated to be an important source of potable water for the city of Wroclaw which is likely to start operating in the near future.

The protection zone of the Bogdaszowice water-bearing structure was established bearing in mind that the aquifer is more vulnerable in the southern part, where vertical leakage times are of durations shorter than 5 years, while lateral inflow with a 25-year isochrone was confirmed by calculations of forward pathlines.

\section{Acknowledgements}

Studies were based on projects realised within the Ministry of the Environment programme for MGB protection strategy in Poland.

\section{References}

Gurwin, J., 2010. Ocena odnawialności struktur wodonośnych bloku przedsudeckiego. Integracja danych monitoringowych i GIS/RS z numerycznymi modelami filtracji. [Renewal assessment of water-bearing structures within the Fore-Sudetic Block. Integration of monitoring and GIS/RS data with numerical flow models]. Hydrogeologia Acta Universitatis Wratislaviensis 3258, Wrocław, $218 \mathrm{p}$.

Gurwin, J., 2012. Wyznaczenie czasu przesączania przez strefę aeracji dla kopalnej struktury wodonośnej w obszarze GZWP 319 na podstawie badań modelowych [Assessment of the unsaturated zone flow time in a buried water-bearing structure within the MGB 319 on the basis of modelling investigations]. Gospodarka Wodna 7/12, 287-291.

Gurwin, J. \& Lubczyński, M., 2005. Modeling of complex multi-aquifer systems for groundwater resources evaluation-Swidnica study case (Poland), Hydrogeology Journal 13, 627-639.

Gurwin, J. \& Poprawski, L., 2008. Analiza możliwości wykorzystania zasobów wód podziemnych w oparciu o numeryczne modele wybranych struktur wodonośnych rejonu Wrocławia [Analysis of potential groundwater resources use on numerical models of selected hydrogeological structures near Wrocław]. Biuletyn PIG Hydrogeologia 431, 41-48.

Gurwin, J. \& Serafin, R., 2007. Numeryczny model filtracji systemu wodonośnego GZWP 322 Oleśnica [Numerical groundwater flow model of the MGB no 322 Aquifer System]. [In:] Wspótczesne problemy hydrogeologii 13, AGH Kraków, 655-666.

Gurwin, J. \& Serafin, R., 2008. Budowa przestrzennych modeli koncepcyjnych GZWP w systemach GIS zintegrowanych z MODFLOW [Design of 3D conceptual models of MGBs using GIS integrating in MODFLOW]. Biuletyn PIG Hydrogeologia 431, 49-59.

Harbaugh, A.W., Banta, E.R., Hill, M.C. \& McDonald, M.G., 2000. MODFLOW-2000 The US Geological Survey modular ground-water model-user guide to modularization concepts and the groundwater flow process. U.S. Geological Survey Open-File Report 00-92, $121 \mathrm{p}$.

Herbich, P., Kapuściński, J., Nowicki, K., Prażak, J. \& Skrzypczyk, L., 2009. Metodyka wyznaczania obszarów ochronnych głównych zbiorników wód podziemnych dla potrzeb planowania $i$ gospodarowania wodami w obszarach dorzeczy [Methodology of protection zone determination of the major groundwater basins for planning and management water in the basin area]. Polish Ministry of the Environment, Warszawa, $59 \mathrm{p}$. 
Kleczkowski, A.S. (Ed.), 1990. Mapa Głównych Zbiorników Wód Podziemnych wymagajacych szczególnej ochrony, 1:500 000 [Map of the Major Groundwater Basins (MGBs) of Poland requiring special protection, 1:500 000]. AGH - Kraków.

Macioszczyk, T. (1999). Time of the vertical seepage as an indicator of the aquifers' vulneralibity (in Polish). Przeglad Geologiczny 47, 731-736.

McDonald, M.G. \& Harbaugh, A.W., 1988. A Modular Three-Dimensional Finite-Difference Ground-Water Flow Model. U.S. Geological Survey Open-File Report, Washington, $586 \mathrm{p}$.

Paczyński, B. \& Sadurski, A. (Eds), 2007. Hydrogeologia regionalna Polski. [Regional hydrogeology of Poland]. Polish Geological Institute - National Research Institute, Warszawa, $542 \mathrm{p}$.

Sachanbiński, M., Kryza, J., Poprawski, L., Staśko, S., Gurwin, J., Kryza, H. \& Szponar, A., 2001. Analiza aktualnego stanu rozpoznania warunków hydrogeologicznych regionu wroctawskiego oraz wytypowanie zbiorników wód podziemnych i struktur wodonośnych dla alternatywnego zaopatrzenia w wode miasta Wroctawia [Analysis of the current state of the hydrogeological conditions of the Wroclaw region and selection of groundwater reservoirs and aquifers structures for alternative water supply of the city of Wroclaw]. Project report, Institute of Geological Sciences, Wrocław University, Wrocław.

Witczak, S. (Ed.), 2005. Mapa wrażliwości wód podziemnych na zanieczyszczenie 1:500 000. [Vulnerability map of groundwaters 1:500 000]. Arcadis Ekokonrem, Warszawa.

Witczak, S. \& Żurek, A. (1997). Use of soil-agricultural maps in the evaluation of protective role of soil for groundwater (in Polish). [In]: A. S. Kleczkowski (Ed.) Metodyczne podstawy ochrony wód podziemnych, AGH, Kraków, 155-181.

Manuscript submitted 17 December 2014 Revision accepted 18 June 2015 